Птиця Н.В., Ковцур К.Г.

Харківський національний автомобільно-дорожній університет, Харків, Україна

\title{
ДО ПИТАННЯ ВИЗНАЧЕННЯ ХАРАКТЕРУ РОЗТАШУВАННЯ ВАНТАЖООДЕРЖУВАЧІВ ПРИ ДОСЛІДЖЕННІ СИСТЕМИ ДОСТАВКИ
}

\begin{abstract}
Роздрібний ланцюг постачань під тиском високого рівня конкуренції на ринку змушує інших учасників процесу загострювати свою увагу на підвищенні ефективності операцій та визначенню параметрів процесу доставки. Особливістю доставки вантажів в роздрібну торгівельну мережу є територіальне розосередження торгових точок, що визначає розсіювання вантажопотоку у просторі та часі. Існуючі шляхи підвищення ефективності організації руху матеріального потоку $\epsilon$ історично сформовані технологічні процеси у логістичному ланцюгу постачань: розробка схем завезення товарів у торгові точки, визначення раціональних розмірів партій і частоту поставок, формування раціональних маршрутів і графіків завезення товарів, визначення структури парку рухомого складу, та інші технологічні процеси, що дозволяють оптимізувати логістичні витрати. Існуючі підходи до визначення характеристик району перевезень та дислокації торгових точок доводять, що прийняті в досліджених роботах допущення про рівномірність розташування торгових точок в районі обслуговування прийняті для спрощення вирішення задач 3 раціоналізації перевезень. Проаналізовані підходи та залежності не відповідають реальним процесам, що призводить до значних відхилень реальних та модельних значень при визначенні умов роботи транспорту в ланцюгу постачань. Пропонується виявити та формалізувати закономірності розташування торгових точок в районі обслуговування, що дозволить 3 достатнім ступенем точності визначати умови роботи транспорту в ланцюгу постачань.

Ключові слова: система доставки, логістичні витрати, щільність торгових точок, витрати на транспортування, район обслуговування, формат торгової точки, роздрібна торгівельна мережа.
\end{abstract}

\section{ВСТУП}

На сьогодні особливістю взаємовідносин у роздрібному ланцюгу постачань $є$ високий рівень конкуренції між роздрібними точками, що змушує інших учасників ринку загострювати увагу більше на ефективності операцій, ніж на підвищенні прибутку. За даними аналітиків з кожним роком спостерігається приріст обсягів перевезень вантажів всередині середніх та великих міст. При цьому значна частка загального товарообігу припадає саме на ці типи міст, де зосереджена роздрібна торгівельна мережа. Оскільки потік матеріальних ресурсів при русі до кінцевого споживача через комунікаційну мережу постійно збільшується у вартості, тому важливим $є$ пошук раціональних технологічних рішень організації процесу доставки вантажів в роздрібну торгівельну мережу, що забезпечить максимальну ефективність їх функціонування.

\section{АНАЛІЗ ЛІТЕРАТУРНИХ ДАНИХ ТА ПОСТАНОВКА ПРОБЛЕМИ}

Розподіл матеріальних ресурсів логістичним каналом обумовлює необхідність залучення додаткових учасників (дистриб'юторів, перевізників) до процесу доставки. Правильність вибору і економічна обгрунтованість залучення учасників $\epsilon$ основними факторами, що визначають раціональність структури ланцюга постачань. Особливістю доставки вантажів в роздрібну торгівельну мережу $є$ територіальне розосередження торгових точок, що визначає розсіювання вантажопотоку у просторі та часі $[1,2]$. Основними тенденціями роботи з роздрібною торгівельною мережею за останні роки $є$ зменшення розміру замовлення торговою точкою через зменшення складських приміщень, висока періодичність постачань, збільшення вимог до часу на виконання замовлення та організація доставки безпосередньо від виробника (дистриб'ютора) до роздрібної торгової точки, минаючи оптові бази. Раціоналізація параметрів транспортного процесу розглядається і в багатьох роботах, як запорука ефективного функціонування підприємства за умови визначення кількості пунктів заїзду на маршрутах $[1,3]$.

Шляхами підвищення ефективності організації матеріального потоку є історично сформовані технологічні процеси на підприємствах-учасниках логістичного ланцюга постачань: розробляються схеми завезення товарів у торгові точки, визначаються раціональні розміри партій поставок і частота завозу, розробляються раціональні маршрути і графіки завезення товарів, визначається структура парку рухомого складу, та інші технологічні процеси, що дозволяють оптимізувати витрати на просування матеріального потоку. Вагомими критеріями для вибору способу доставки чи постачальника в роботі [3] виступають віддаленість постачальника від споживача, терміни 
виконання поточних і екстрених замовлень, наявність резервних потужностей, організація управління якістю у постачальника.

Серед робіт останнього періоду виділяється робота [4], в якій відзначається, що необхідною умовою для вибору каналу розподілу, та оптимізації всього логістичного процесу на макрорівні, $є$ наявність на ринку великої кількості посередників. Зокрема, оптимізація каналу розподілу, а потім і логістичного ланцюга, можлива при наявності на товарному ринку великої кількості підприємств, які здійснюють функцію опту. В роботі приймається рівномірне їх розподілення у регіоні 3 метою можливості швидкого обслуговування роздрібних точок.

В роботах [2-5] відзначається значний вплив таких показників, як віддаленість підприємствавиробника (або постачальника) і вантажоодержувачів, щільність дислокації торгових точок і розмір партії вантажу на критерій ефективності, а саме витрати на доставку вантажу, але представлені напрямки вдосконалення процесу доставки, що пропонуються в роботах, орієнтовані на конкретні торгові підприємства та потребують перегляду в кожному конкретному випадку. Це не дає змоги формалізувати вимоги до роботи учасників процесу доставки навіть в межах більш-менш великого регіону, а також визначити тенденції зміни характеристик умов перевезень.

У роботі [6] Міротін Л.Б. зауважує можливість використання графічного методу для вирішення задачі визначення кількості об’єктів логістичної системи, так як їх кількість прямопропорційно впливає на логістичні витрати системи. При оцінці впливу до уваги приймаються середні значення відстаней між об'єктами, що свідчить про рівномірність їх розташування у районі функціонування.

3 позиції геологістичних систем важливими є гравітаційні моделі, які враховують не тільки відстань перевезень, а і вплив великих центрів тяжіння матеріалопотоків, що дає змогу спрогнозувати та оптимізувати матеріальні потоки. Цей розвиток дозволив Рейлі в роботі [7] створити модель торговельної гравітації, яка інтерпретуючись до сучасних торгівельних мереж, полягає в тому, що торгівельні точки більшого розміру притягують до себе більшу кількість покупців, готових долати значні відстані, що дає змогу рівномірного розташування таких об'єктів у регіоні. Аналогічно в роботі [8] при дослідженні транспортної і розподільчої геологістики на прикладі західного регіону України вказується на ентропійну міру концентрації у районі обслуговування логістичних стейкхолдерів транспортного процесу.

Останні дослідження по плануванню міст направлені на підвищення зручності для життя в них. Ще у роботі [9] стверджується, що головною метою містобудування було створення планування, яке характеризувалося наявністю рівновіддалених зон максимальної пішохідної доступності (мікрорайонів), в центрах яких повинні розташовуватися обслуговуючі район підприємства торгівлі, магазини, школи, лікарні та ін. У роботах дослідників район обслуговування, в якому знаходяться торгові точки, приймається у якості допущення у формі кола, а щільність дислокації торгових точок в районі перевезень рівномірна (рис. 1). Рівномірність розосередження та концентричність приймаються за базові принципи організації процесу доставки у мережевій роздрібній торгівлі [10, $11]$.

В роботі [12] при розгляді розміщення об’єктів логістичної системи на основі загальних приведених витрат представлено математичну модель оптимальної довжини ланцюга постачань, вагомими параметрами в якій є площа території обслуговування, кількість кінцевих споживачів, ціна одиниці вантажу та відносне зміщення постачальника від центру тяжіння території обслуговування.

Навіть законодавчо нормативи забезпеченості населення торговельними площами передбачають комплекс заходів 3 рівномірного та оптимального розміщення об'єктів роздрібної торгівлі по території регіонів з метою максимального їх наближення до кінцевих споживачів [13].

Отже вирішення задач зменшення витрат на доставку, в яких приймається рівномірне розташування торгових точок, притаманне тільки для торгівельних точок великих форматів. Виходячи з базових положень маркетингу, торгові точки дрібних форматів у свідомості споживачів повинні відрізнятися якістю товарів і послуг, чого можливо досягти при утриманні кінцевої ціни на товари на мінімальному рівні, шляхом підвищення ефективності організації процесу доставки. Так, поодинокі торговельні об'єкти невеликого формату не витримують конкуренції з торговими точками великих форматів, і саме тому не рівномірно розташовані у районі обслуговування. Забезпечити такій торговій точці необхідний споживчий потік, обсяг обороту в конкурентному оточенні вкрай складно. 


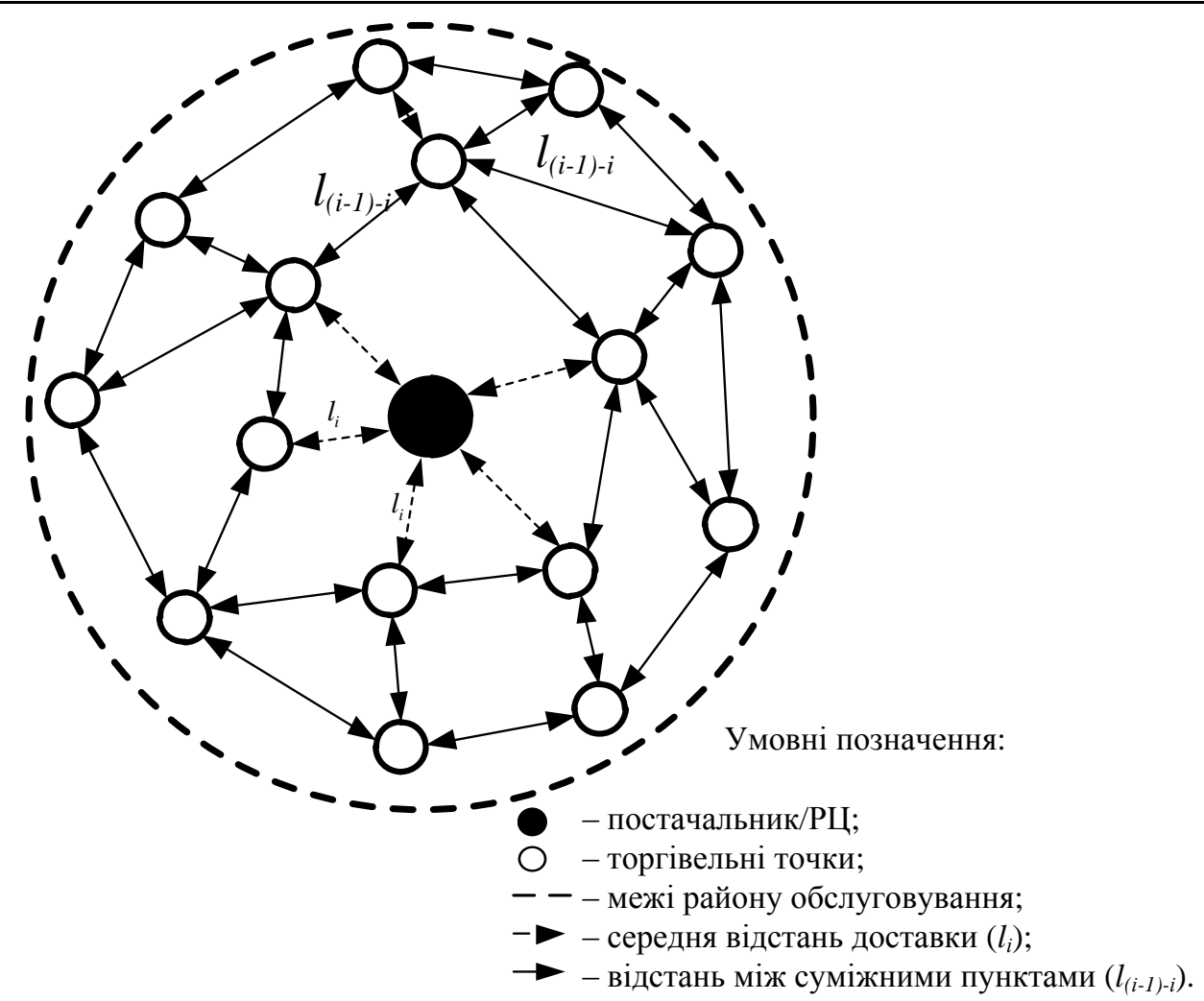

Рисунок 1 - Схема рівномірного розташування кінцевих споживачів у районі обслуговування

\section{ЦІЛЬ ТА ЗАДАЧІ ДОСЛІДЖЕННЯ}

Результати аналізу існуючих підходів до визначення характеристик району перевезень та дислокації торгових точок доводять, що прийняті в досліджених роботах допущення про рівномірність розташування торгових точок в районі обслуговування значно спрощують складність вирішення задач з раціоналізації перевезень, але, в той же час, не відповідають реальним процесам. Тому, метою даного дослідження $\epsilon$ виявлення закономірності розташування торгових точок в районі обслуговування, що дозволило б з достатнім ступенем точності визначити умови роботи транспорту в ланцюгу постачань.

\section{РЕЗУЛЬТАТИ ДОСЛІДЖЕНЬ}

Основними параметрами, що характеризують умови перевезень і впливають на технологічні і економічні показники роботи транспорту при доставці товарів в роздрібну торгівельну мережу міст $\epsilon$ відстань доставки вантажів, розмір партії вантажу та пробіг автомобілю між суміжними пунктами заїзду на маршруті, який можна визначити через щільність дислокації пунктів завозу на території району перевезень. Загальновідомо, що при розширенні роздрібної торгівельної мережі, місце дислокації торгової точки обирається з огляду на максимальне наближення до споживачів. Згідно моделі виявлених переваг зосередження групи торгових точок дрібних форматів підвищує їх купівельну привабливість. Це справедливо для торговельних точок дрібних форматів, які зазвичай локалізуються поблизу один одного, утворюючи торгівельні майданчики, що являють собою певні кластери. Ці кластери являють собою групи торгових точок, що об'єднані між собою за близькістю розташування один до одного та утворюють консолідуючий попит на товар у виробників або дистриб'юторів. Кожен такий кластер характеризується високою щільністю дислокації торгових точок, низькою щільністю населення в середині нього та розташуванням в переважній більшості поблизу пасажиропоглинаючих або пасажироутворюючих пунктів. Ще однією 3 характеристик такого кластеру є кількість партій вантажів, що надходить за певний проміжок часу, наприклад, за добу. У випадку, коли постачальник обслуговує кілька торгівельних точок, відстань між суміжними пунктами заїзду $\left(l_{(i-1)-i}\right)$ дорівнюватиме нулю (рис. 2$)$. 


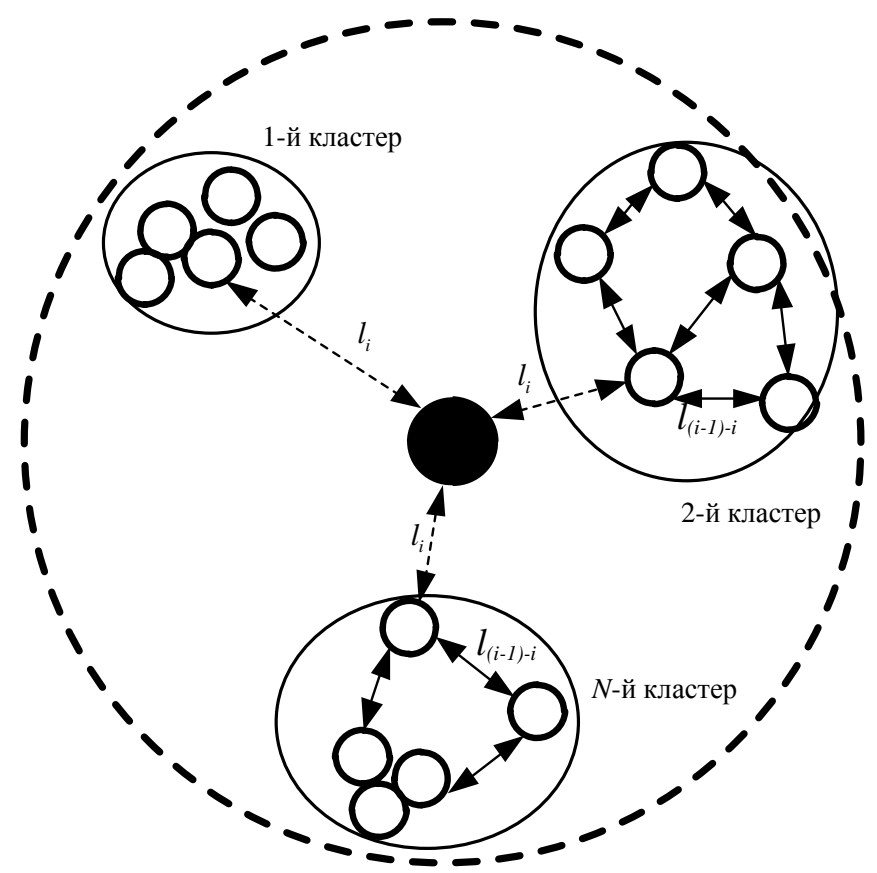

Рисунок 2 - Схема нерівномірного розташування кінцевих споживачів у районі обслуговування

\section{ОБГОВОРЕННЯ РЕЛУЛЬТАТІВ ДОСЛІДЖЕННЯ}

Висока щільність дислокації торгових точок кожного кластеру утворює і високий вхідний вантажопотік, що може призвести до незручностей з організації дорожнього руху (наприклад, затори через припарковані транспортні засоби, тощо) поблизу них через відсутність спеціалізованих майданчиків для автомобілів, що здійснюють доставку товарів. Саме тому визначення просторової структури торгових точок дасть змогу побудувати більш точну модель розподілу вантажопотоків в районах обслуговування. Дана модель може застосовуватись як перевізниками - для визначення параметрів роботи транспорту, так і органами місцевої влади - для планування стратегій розвитку вантажних міських перевезень. Збір даних про переміщення транспортних засобів з вантажем, час та місце їх розвантаження може бути визначено за допомогою геоінформаційних систем, однак таке вирішення питання $є$ дороговартісним і потребує злагодженої роботи усіх учасників процесу доставки.

Як відомо, параметри стейкхолдерів транспортного процесу, характеризуються саме взаємним розташуванням і обсягами вивезення та завезення вантажів i, таким чином, безпосередньо впливають на процес формування розвізних маршрутів. Збільшення кількості торговельних точок і обсягів завезень до них призводить до більшої кількості розвізних маршрутів або до підвищення номінальної вантажності транспортного засобу, що працює на маршруті. Але, якщо торгові точки, що обслуговують на одному маршруті, розташовуються поряд, то виникає необхідність корегування параметрів процесу.

Розширення асортиментного ряду продовольчих товарів на споживчому ринку призведе до збільшення кількості транспортних операцій для забезпечення системи доставки. Застосування існуючих інструментів для організації просування товарів на кінцевій ланці ланцюга постачань у таких умовах ставить під сумнів ефективність технологічних рішень.

\section{ВИСНОВКИ}

Результати проведеного аналізу літературних джерел з питань оптимізації системи доставки товарів на останньому етапі ланцюга постачань в роздрібну торгівельну мережу представляють в своїй більшості район обслуговування як полігон з рівномірно розташованими торговими точками у ньому. Результати отриманих математичних моделей, що побудовані на даному допущенні, мають значні відхилення від реальних значень. Допущення про рівномірність розташування торгових точок $\epsilon$ справедливим для торгових точок великих форматів. Так, торгові точки дрібних форматів утворюють певні майданчики-кластери, які характеризуються високою щільністю торгових точок та кількістю партій завезення в них. Оскільки транспортний процес є ключовим елементом ефективності функціонування ланцюга постачань в умовах жорсткої конкуренції на споживчому 
ринку, то постає питання формалізації просторової структури торгових точок, що дасть змогу побудувати більш точну модель розподілу вантажопотоків в районах обслуговування.

\section{ПЕРЕЛІК ДЖЕРЕЛ ПОСИЛАНЬ} $503 \mathrm{c}$.

1. Уотерс Д. Логистика. Управление цепью поставок: пер. с англ. - М.: ЮНИТИ-ДАНА, 2003. -

2. Сидоров Д. Розничные сети. Секреты эффективности и типичные ошибки при работе с ними / - М.: Вершина, 2007. - 230 с.

3. Нагорний Є.В. Комерційна робота на транспорті: підручник / Є.В. Нагорний, Н.Ю. Шраменко, Г.І. Нестеренко // Харків: ХНАДУ, 2012. 268 с.

4. Гаджинский А.М. Логистика: Учебник. - 11-е изд. перераб. и доп. - М.: Издательскоторговая корпорация «Дашков и К», 2005. - 432 с.

5. Воркут А.И. Транспортное обслуживание торгово-оптовых баз / А.И. Воркут, А.Г. Калинин, А.Г. Ковалик, А.С. Рудык // - К.: Техніка, 1985. - 112 с.

6. Транспортная логистика / Под ред. Л.Б. Миротина. - М.: Транспорт, 1996. - 211с.

7. Reilly's Law of Retail Gravitation. URL: geography.about.com /cs/citiesurbangeo/a/aa041403a.htm (дата звернення: 10.06.2020).

8. Сеньків M.I. Транспортна і розподільча геологістика в західному регіоні України: Дис ... канд. техн. наук: 11.00.02. / ЛНУ ім. І. Франка: Львів, 2017. 210 с.

9. Ефремов И.С. Городской пассажирский транспорт и АСУ транспорта / И.С. Ефремов, Г.А. Гольц / под ред. В.М. Кобозева. - М.: Наука, 1988. - 480 с.

10. Ковцур К.Г. Резервування провізних можливостей парку автомобілів у логістичних ланцюгах постачань споживчих товарів: Дис ... канд. техн. наук: 05.22.01. / ХНАДУ: Харків, 2015. $256 \mathrm{c}$.

11. Птиця Н.В. Формування процесу доставки дрібнопартіних вантажів у логістичній системі роздрібної торгівельної мережі: Дис ... канд. техн. наук: 05.22.01. / ХНАДУ: Харків, 2020. 185 с.

12. Потаман Н.В. Выбор рационального количества складов в цепочке поставок продукции автомобильным транспортом в межрегиональном сообщении: Дис... канд. техн. наук: 05.22.01 Транспортные системы / ХНАДУ. - Харьков, 2010. - 243 с.

13. Герасимчук 3.В. Регіональні логістичні системи: теорія та практика: Монографія / 3.В. Герасимчук, Л.Л. Ковальська, Н.В. Хвищун, О.Д. Мороз // - Луцьк: РВВ ЛНТУ, 2010. - 256 с.

\section{PREFERENCES}

1. Uoters D. (2003). Logistika. Upravleniye tsep'yu postavok: per. s angl, 503 p.

2. Sidorov D. (2007) Roznichnyye seti. Sekrety effektivnosti i tipichnyye oshibki pri rabote s nimi, $230 \mathrm{p}$.

3. Nahornyy YE.V., Shramenko N.YU., Nesterenko H.I. (2012) Komertsiyna robota na transporti: pidruchnyk Kharkiv: KHNADU, 268 p.

4. Gadzhinskiy A.M. (2005) Logistika: Uchebnik, 432 p.

5. Vorkut A.I., Kalinin A.G., Kovalik A.G., Rudyk A.S. (1985) Transportnoye obsluzhivaniye torgovo-optovykh baz. Tekhníka, $112 \mathrm{p}$.

6. Mirotin L.B (1996). Transportnaya logistika, 211.

7. Reilly's Law of Retail Gravitation. URL: geography.about.com /cs/citiesurbangeo/a/aa041403a.htm.

8. Sen'kiv M.I. (2017) Transportna i rozpodil'cha heolohistyka v zakhidnomu rehioni Ukrayiny: Candidate's thesis, 210.

9. Yefremov I.S., Gol'ts G.A. (1988) Gorodskoy passazhirskiy transport i ASU transporta. pod red. V.M. Kobozeva. Nauka, 480 p.

10. Kovtsur K.G. (2015). Rezervuvannya proviznykh mozhlyvostey parku avtomobiliv u lohistychnykh lantsyuhakh postachan' spozhyvchykh tovariv: Candidate's thesis, 256.

11. Ptitsa N.V. (2013). Formuvannya protsesu dostavky dribnopartinykh vantazhiv u lohistychniy systemi rozdribnoyi torhivel'noyi merezhi: Candidate's thesis, 185.

12. Potaman N.V. (2010). Vyibor ratsionalnogo kolichestva skladov v tsepochke postavok produktsii avtomobilnyim transportom v mezhregionalnom soobschenii: Candidate's thesis, 243.

13. Herasymchuk Z.V., Koval's'ka L.L., Khvyshchun N.V., Moroz O.D. (2010) Rehional'ni lohistychni systemy: teoriya ta praktyka. Monohrafiya Luts'k: RVV LNTU. 256 p. 


\section{Ptytsia N.V., Kovtsur E.G. On the question of determining the nature of the location of consignees in the study of the delivery system}

The retail supply chain, under pressure from high levels of competition in the marketplace, is forcing other participants in the process to turn their attention to improving the efficiency of operations and defining the parameters of the delivery process. A feature of the delivery of goods to the retail trade network is the territorial dispersion of retail points, which determines the dispersion of freight traffic in space and time. The existing ways to improve the efficiency of organizing the movement of material flow are historically established technological processes in the logistics supply chain: development of schemes for the delivery of goods to retail points, determination of rational batch sizes and frequency of deliveries, formation of rational routes and schedules for the delivery of goods, determination of the structure of the rolling stock fleet and other technological processes that allow to optimize logistics costs.

Solutions to the problems of reducing delivery costs, in which a uniform arrangement of points is accepted, which is inherent only for large format retail outlet spots. Small-format retail outlet spots cannot compete with large-format retail outlet spots, therefore, they are not evenly located in the service area. Existing approaches to determining the characteristics of the transportation area and the location of outlets show that the assumption of the uniformity of the location of points in the service area is adopted in order to simplify the solution of problems to rationalize transportation. The analyzed approaches and dependencies do not correspond to real processes, leading to significant deviations of real and model values when determining the operating conditions of transport in the supply chain. It is proposed to identify and formalize the patterns of the location of points in the service area, which will allow with a sufficient degree of accuracy to determine the operating conditions of transport in the supply chain.

Key words: delivery system, logistics costs, density of retail outlet spots, transportation costs, service area, format of retail outlet spots, retail.

ПТИЦЯ Наталія Василівна, кандидат технічних наук, асистент кафедри транспортних систем і логістики, Харківський національний автомобільно-дорожній університет, e-mail: nataliya.ptitsa@gmail.com. https://orcid.org/0000-0002-4559-7651

КОВЦУР Катерина Григорівна, кандидат технічних наук, доцент кафедри транспортних систем i логістики, Харківський національний автомобільно-дорожній університет, e-mail: kovtsyr@ukr.net. http://orcid.org/0000-0002-0445-5438

PTYTSIA Natalia Vasylivna, Ph. D. of Engineering, assistant of Transport Systems and Logistics Department, Kharkiv National Automobile and Highway University, e-mail: nataliya.ptitsa@gmail.com. https://orcid.org/0000-0002-4559-7651

KOVTSUR Kateryna Grigorivna, Ph. D. of Engineering, Associate Professor of Transport Systems and Logistics Department, Kharkiv National Automobile and Highway University, e-mail: kovtsyr@ukr.net. http://orcid.org/0000-0002-0445-5438

DOI 10.36910/automash.v1i16.515 